KUML 1997-98 


\section{KUML 1997-98 Årbog for Jysk Arkæologisk Selskab}

With summaries in English 
Redaktion: Hans Jorgen Madsen og Jesper Laursen

\section{Omslag: Louise Hilmar}

Tilrettelagning: Narayana Press

Tryk: Narayana Press

Skrift: Bembo 12/13

Papir: $115 \mathrm{~g}$ Arctic Silk

Copyright (C) 1998 by Jysk Arkaologisk Selskab

ISBN 87-7288-597-1

ISSN 0454-6245 


\section{Indhold/Contents}

Hans Jorgen Madsen og Else Roesdahl: Olaf Olsen 70 år $\ldots \ldots \ldots \ldots \ldots \ldots \ldots \ldots$

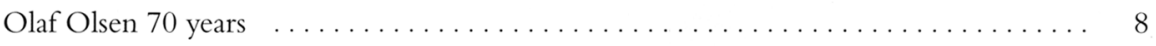

Søren H.Andersen: En mønstret pragtøkse fra ældre Ertebølletid $\ldots \ldots \ldots \ldots \ldots \ldots$.

A Magnificent ornamented axe from the Early

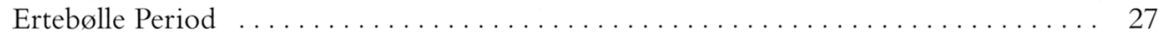

Henrik Skousen: Rønbjerg Strandvolde - en kystboplads

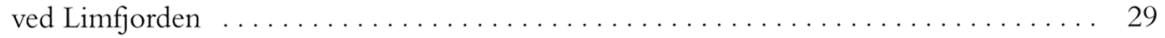

Rønbjerg Strandvolde - a coastal settlement by the Limfjord $\ldots \ldots \ldots \ldots \ldots \ldots \ldots 71$

Lisbeth Christensen: Vandet skole - en ældre romertidsgrav med

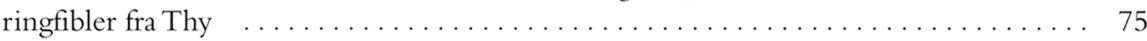

An Early Roman Iron Age grave with ring brooches from

Vandet School in Thy ........................................ 103

Bjarne Henning Nielsen: Jernalderfund fra Egådalen . . . . . . . . . . . . . . . . . 105

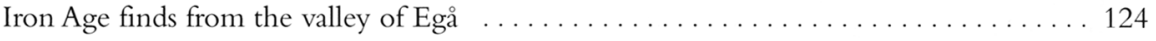

Elisabeth Barfod Carlsen: Et smykke i slægt med guldbrakteaterne $\ldots \ldots \ldots \ldots \ldots \ldots . \ldots 127$

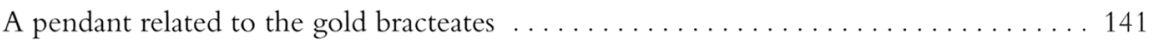

Claus Feveile, Stig Jensen og Kaare Lund Rasmussen: Produktion

af drejet keramik i Ribeområdet i sen yngre germansk jernalder $\ldots \ldots \ldots \ldots \ldots \ldots 143$

The production of thrown pottery in the Ribe area towards

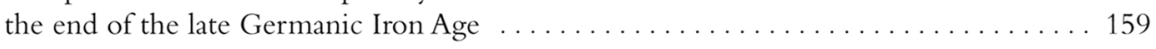

Ole Crumlin-Pedersen: Skibsfundene fra Hedeby $\ldots \ldots \ldots \ldots \ldots \ldots \ldots \ldots$

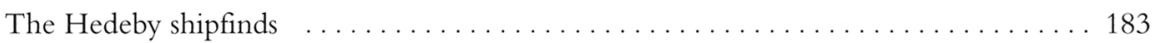

Anne Pedersen: Bidselbeslag fra Bøgeskov Strand . . . . . . . . . . . . . . . . . . . 185

A Harness Cheek-piece from Bøgeskov Strand ....................... 194

Bente Holmberg og Jan Skamby Madsen: Da kom en snekke ... . . . . . . . . . . . . . 197

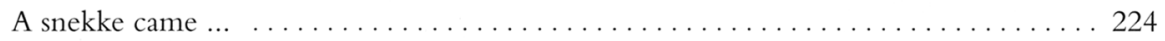

Hans Skov: Udgravningerne i Århus Midtby 1994-97 . . . . . . . . . . . . . . . . 227

The excavations in the centre of Aarhus 1994-97 . . . . . . . . . . . . . . . . . 292

Thomas Bertelsen: Kirketage ........................................ 295

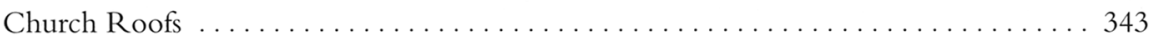

Anmeldelser .................................................. 347

Jysk Arkæologisk Selskab 1997 . . . . . . . . . . . . . . . . . . . . . . . . 369

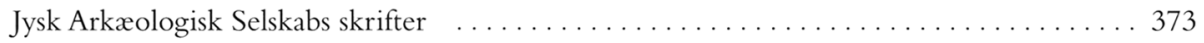




\title{
Et smykke i slægt med guldbrakteaterne
}

\author{
Af Elisabeth Barfod Carlsen
}

En af de første dage i 1998 indleverede fru Esther Fisker,Viby ved Århus, et fint lille guldsmykke til Moesgård Museum og kunne samtidig fortælle nærmere om dets fundhistorie. Der er tale om et lille rundt hængesmykke, og fru Fisker fandt det engang i 1938 eller 1939, da hun som ung var ude at bade øst for Husodde på nordsiden af Horsens Fjord. Smykket lå i strandkanten vistnok ud for Elbæk Skov, hvor en lav skrænt hæver sig ved kysten (fig. 1). Esther Fisker tog smykket med hjem til familien, og da en søster nogen tid senere skulle på tur til København med sin seminarieklasse, fik hun smykket med og præsenterede det på Nationalmuseet. Af ukendte grunde blev det ikke dengang inddraget som danefæ. I de følgende år blev smykket omhyggeligt opbevaret, og da fru Fisker for nylig læste en diskussion om danefæ i dagspressen, tog hun smykket med til Moesgård Museum, da hun mente, det kunne have en arkæologisk interesse. Det havde det, og smykket er nu omsider inddraget i Nationalmuseets samling som danefæ. Smykket tilhører en af de mest guldrige perioder i Danmarks oldtid, xldre germansk jernalder eller folkevandringstid, som den også kaldes; men fundet er både meget smukt og af usædvanlig type, så det kan nok fortjene en nærmere omtale. ${ }^{1}$

Smykket er af guld og vejer 2,8 gr. (fig. 2). Det har en diameter på 2,2 $\mathrm{cm}$. og er gjort af en tynd guldplade med påloddet øsken. I pladens midte ses en dyrefigur. Motivet er gennembrudt, så dyret står alene. Langs bortens to kanter ses en perlet filigrantråd, og i borten ses kringler lavet af en tilsvarende tråd. Øsknet er riflet og sat henover en af disse filigrankringler. På dyremotivet er også sat perlede filigrantråde.

Dyret består af et hoved med en halvrund øjenbue og en rund cirkel som selve øjet/pupilen (fig. 3). Fra øjenbuens venstre side strækker halsen og kroppen sig og munder ud i et rundt lår. Det andet lår ses i højre side på vej ud af motivet. Foran øjet ses næbbet eller kæberne. Overkæben ligger henover underkæben.

Indledende har man udbanket en tynd plade af guld. Pladens cirkulære form er opnået ved hjælp af en passer, og dyrefiguren er blevet markeret ved indridsning. Den gennembrudte figur er sandsynligvis slået ud med en mejsel fra bagsiden. Når det virker sandsynligt, skyldes det, at der 


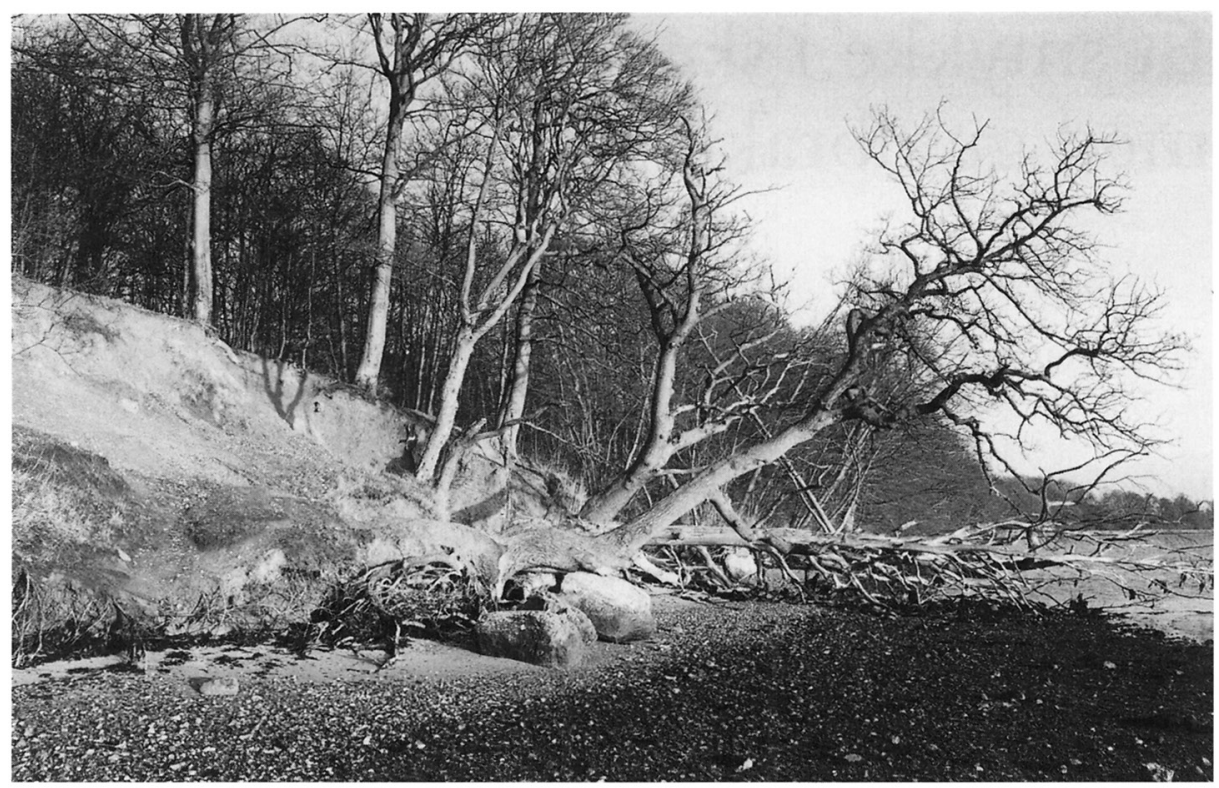

Fig. 1. Fundstedet ved Elbæk Skov, Husodde ved nordsiden af Horsens Fjord. Foto: Hans Skov.

The find spot at Elbæk Skov, Husodde, on the northern side of Horsens Fjord. Photographed by Hans Skov.

langs dyrefigurens omrids på hængesmykkets forside ses svagt opbøjede kanter, der stammer fra tryk fra bagsiden. På selve dyret er påsat to rækker af perlede filigrantråde, mens en tredie guldtråd, der er udekoreret, er anbragt imellem og oveni de to førstnævnte. Dernæst er dekorationen af kantens og bortens kringler fastloddet; denne er også udført i perlet filigrantråd.Til sidst er øsknet lidt groft fastloddet, og smykket er poleret med en sten i en blød stenart.

Smykket svarer i mangt og meget til de såkaldte guldbrakteater fra folkevandringstiden. I det sammenlignelige brakteatmateriale er motivet produceret ved hjælp af en matrice. En matrice er en fordybet form, hvori metallet formes enten ved presning eller ved slag. Metalpladen făr derved et motiv i ophøjet relief. Det ophøjede relief på hængesmykket fra Elbæk Skov er derimod skabt ved hjælp af filigrantråde.

Det ene lår har været svagt fæstet til kanten og er senere repareret (fig. 2). En tynd guldplade er loddet fast til støtte for dyrets lår.Ved lodning af filigrantråde eller som her ved reparationen er der brugt en legering med et lavere smeltepunkt end smykkets smeltepunkt. Alligevel er forsidens filigranornamentik smeltet sammen, og reparationen må derfor være foretaget efter, at hængesmykket var færdiggjort. Der er slid på bortens to kanttråde og på dyrefigurens udekorerede guldtråd, mens der ikke er slid på øsknet. 

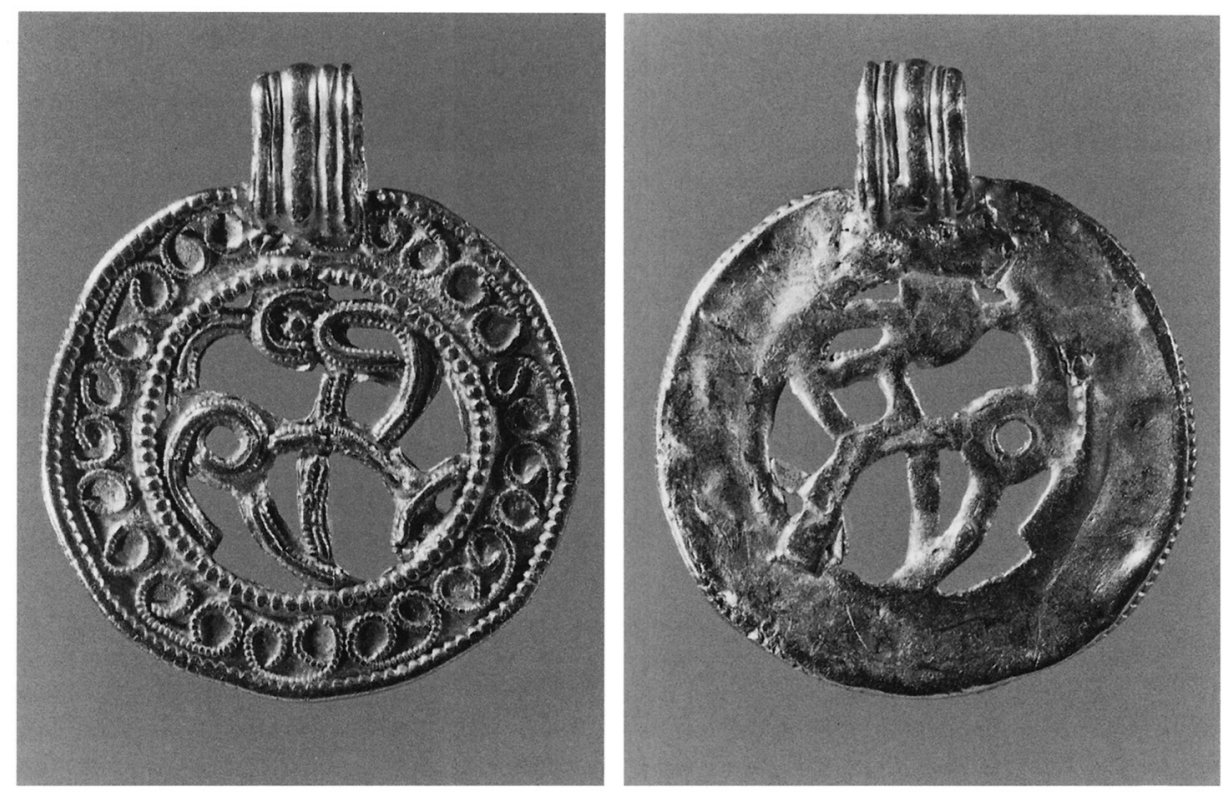

Fig. 2. For- og bagside af guldhængesmykke fra Elbæk Skov. Diameter 2,2 cm. Foto: Preben Dehlholm.

The front and back of the pendant from Elbæk Skov. Diameter $2.2 \mathrm{~cm}$. Photographed by Preben Delholm.

Filigran er en dekorationsmåde for smykker, der opstod i 2. årt. f. Kr. i Egypten ${ }^{2}$, og metoden består i pålodning af tynde guldtråde. Der findes flere slags dekorerede filigrantråde, og på Elbæk Skov smykket drejer det sig om perlede tråde. De ældste perlede filigrantråde i Norden kendes fra smykker fra førromersk jernalder. I romersk og germansk jernalder ses metoden meget ofte. ${ }^{3}$ Størstedelen af alle brakteater har en perlet filigrantråd langs eller på kanten. ${ }^{4}$ Denne tråd er smedet og formet med en perlefil. ${ }^{5}$ Smykker fra folkevandringstiden kan også være dekoreret i granulationsteknik. Her består teknikken i at lodde små guldperler i et dekorativt mønster fast på smykket. Dette ses ofte neden for øsknet på guldbrakteater. I folkevandringstiden dominerer granulation på de æeldst daterede smykker, mens de yngre smykker hovedsagelig er dekoreret med filigran. Granulation anvendes dog stadigvæk på de yngste smykker, når lår og øje i dyreornamentikken skal markeres. ${ }^{6}$

I det efterfølgende afsnit vil jeg forsøge at datere smykket fra Elbæk Skov ud fra guldbrakteaterne og to gennembrudte hængesmykker med filigran fundet i Sverige. 


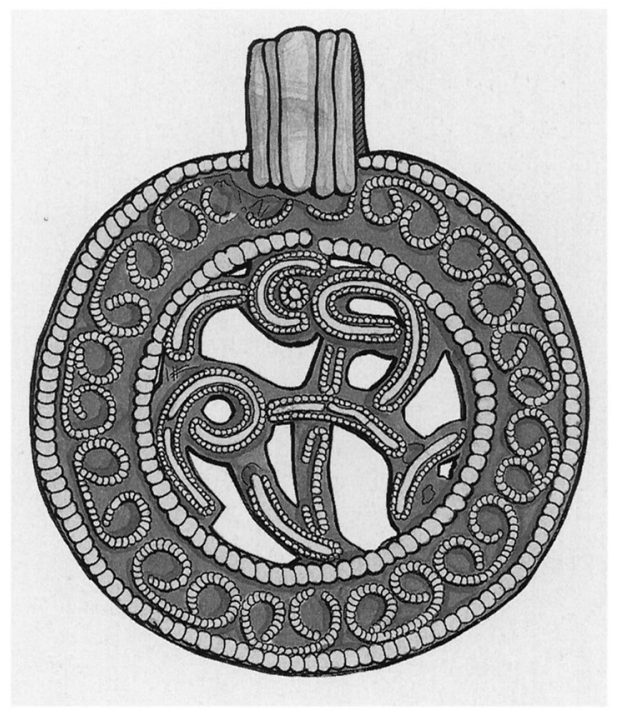

Fig. 3. Guldhængesmykke fra Elbæk Skov. Tegning: Sisse Degner.

The pendant from Elbæk Skov. Drawing by Sisse Degner.

\section{Folkevandringstidens brakteater}

Gennembrudte hængesmykker i guld fra folkevandringstiden er ikke helt ualmindelige. Ofte er de blot dekoreret med geometriske mønstre som f.eks kors. Det er sjældent, at der ses dyreornamentik på dem. Smykker fra folkevandringstiden optræder i Danmark oftest i skatte- eller offerfund, og det gør det vanskeligt at datere deres produktions- og nedlæggelsestidspunkt. Når smykker bliver fundet i grave, er det højest sandsynligt, at den gravlagte har båret smykket $\mathrm{i}$ sin levetid og en datering af smykket fortæller, hvornår den gravlagte døde. Smykker i skatte- eller offerfund kan være arvestykker, og man kan ikke være sikker på, at sammensætningen af et sådant fund afspejler en tidstypisk situation.

På grund af dyreornamentikken kan man forsøge at datere smykket fra Elbæk Skov ved at påvise stilistiske paralleller til veldaterede danske og udenlandske fund. En anden dateringsmulighed er at drage sammenligning med den type hængesmykker, som først og fremmest er kendetegnende for folkevandringstiden, guldbrakteaterne.

En brakteat er en ensidigt præget guldmønt. Ordet brakteat stammer fra den latinske betegnelse bractea, der er betegnelsen for tyndt guldblik. ${ }^{7}$ Guldbrakteaterne tilhører en af de største smykkegrupper i forhistorien. Der er fundet over 900 stykker spredt ud over Skandinavien, det meste af Mellemeuropa og England. ${ }^{8}$ Guldbrakteaterne har siden begyndelsen af forrige århundrede nydt stor opmærksomhed på grund af det ædle metal, den store mængde og deres flotte motiver. Forbilledet er de senromerske medaljoner og guldmønter. En af de første arkæologer, der beskæftigede 
sig med guldbrakteaterne, var C.J.Thomsen. ${ }^{9}$ Han fandt frem til, at en stor del af guldbrakteaterne på grund af runeindskrifterne og den skandinaviske udbredelse måtte være af nordisk oprindelse. ${ }^{10}$ Den svenske arkæolog O.Montelius arbejdede videre med Thomsens ideer og tolkninger og opdelte det voksende guldbrakteatmateriale i otte grupper (AH) og disse betegnelser bruger vi stadigvæk. ${ }^{11}$ Type A forestiller et ansigt set i profil. Der kan være latinske inskriptioner i motivet. Motivet har stor lighed med forbilledet, de senromerske kejsermedaljoner og guldmønter. Type B er brakteater med hele menneskefigurer. Type $\mathrm{C}$ har et profilset ansigt over et firbenet dyr. På B- og C-typen kan runer være en del af motivet. Den yngste gruppe er D-typen (fig. 4), og motivet er her et firbenet fabeldyr set i profil med hoved, krop, lår og fødder. Der optræder derfor kun to ben, dvs. et forben og et bagben. Det mest almindelige motiv består af ét dyr, men i få tilfælde kan to dyr være flettet ind i hinanden og danne hinandens spejlbillede. Type F's motiv er et dyr, der ikke har stilistisk lighed med dyret på D-typen. Type E, G og H er idag ikke typologiseret som folkevandringtidens brakteater og skal dateres til de efterfølgende perioder.

Når denne artikels hængesmykke kan sammenlignes med en brakteat, skyldes det de stilistiske ligheder (fig. 4). Elbæk Skov smykket er opbygget som en brakteat med motivet i midten, en dekoreret bort, en perlet filigrantråd langs kanten og et øsken. Det er også kun dekoreret på den ene side, og hængesmykkets motiv har stor stilistisk lighed med dyremotivet på D-brakteaterne. Det, der adskiller smykket fra de øvrige D-brakteater, er dets tekniske udførelse.

Fig. 4. D-brakteat fundet ved St. Anst i Vestjylland. Diameter 2,3 cm. (Efter Axboe 1985f fig. 471,2b).

D-bracteate. Uncertain find location found at Nørre Hvam near Holstebro. (After Axboe (ed.) 1985 f fig. 471, 2b).

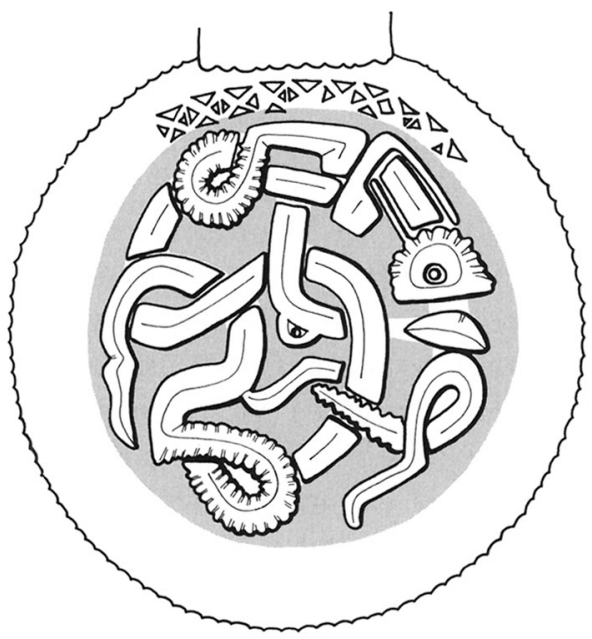


Udbredelseskortet viser, hvor der er fundet D-brakteater gennem årene (fig. 5). Der er endnu ikke fundet D-brakteater på Sjælland med Øerne og Bornholm. D-brakteaterne opstår som ide i Jylland og viser en stilistisk samhørighed inden for denne landsdel. ${ }^{12}$ En stilistisk og kronologisk analyse har vist, at de ældste typer fremkommer i Jylland, og først senere i produktionen bliver de eksporteret, kopieret og imiterede uden for det sydskandinaviske område. ${ }^{13}$ Den stilistiske analyse viste også, at motivet på D-brakteaterne er ensartet inden for størstedelen af Skandinavien, men at de norske eksemplarer dog er afvigende. ${ }^{13}$

Der er forskel på, i hvilken sammenhæng brakteaterne bliver fundet. I Danmark og Sverige bliver de fundet i depoter d.v.s. i skatte- eller offerfund. I depoterne forekommer de oftest med de øvrige brakteattyper og derudover med relieffibler, glasperler og brudguld. I det øvrige udland findes brakteaterne i både grave og depoter. I Norge er der fundet tre brakteater $\mathrm{i}$ tre forskellige grave, mens resten er fremkommet i depoter. I England er alle, på nær nogle få løsfund, fundet i grave. På kontinentet er brakteaterne fundet i grave og depoter. For de udenlandsk fundne ses det klart, at jo tættere på det skandinaviske område desto oftere forekommer de i depoter, mens de, der ligger langt væk fra Skandinavien, forekommer i grave. ${ }^{14}$

Når brakteaterne forekommer i depoter i Skandinavien, er en præcis datering svær at give. Traditionelt har forskningen dateret depoter med brakteater i sidste halvdel af folkevandringstiden, og da D-brakteaterne er de yngst producerede brakteater, er disse depoter derfor dateret et stykke ind i 6. årh. I Malmers kronologiske analyse af skandinaviske depoter med brakteater lægger han vægt på dateringerne af de medfølgende romerske solidi. ${ }^{15}$ I ni depotfund er der sammen med brakteater fundet ialt tyve solidi. Deres prægning ligger mellem 395 til 476 e.Kr. I stedet for at forestille sig en lang omløbstid for solidi, mener Malmer, at brakteatproduktionen skal dateres tidligere. Produktionen af A-brakteater må være begyndt før 450 e.Kr., og han sætter derved D-brakteatproduktionen til 475 e.Kr. eller lidt tidligere. ${ }^{16}$

Ved hjælp af krydsfund er det muligt at datere D-brakteater i grave fundet uden for Skandinavien. D-brakteater fundet i England er nedlagt i kvindegrave i tiden mellem 520-550/60 e.Kr. ${ }^{13}$ Brakteaterne er ofte meget slidte ved nedlæggelsen. De er brugt igennem længere tid, og de har fungeret som etniske markeringer, der viste slægtens oprindelse. ${ }^{17} \mathrm{D}$ brakteater fundet i Mellemeuropa er nedlagt lidt tidligere end i England, dvs. imellem 500-550/60 e.Kr. ${ }^{13}$ På disse eksemplarer af D-brakteater er der en stor variation i den stilistiske udførelse af motivet, og der er derfor tale om imitationer af de sydskandinaviske D-brakteater. D-brakteater i grave uden for det skandinaviske oprindelsesområde må ses som en sidste rest af en nordisk brakteattradition. ${ }^{13}$ 


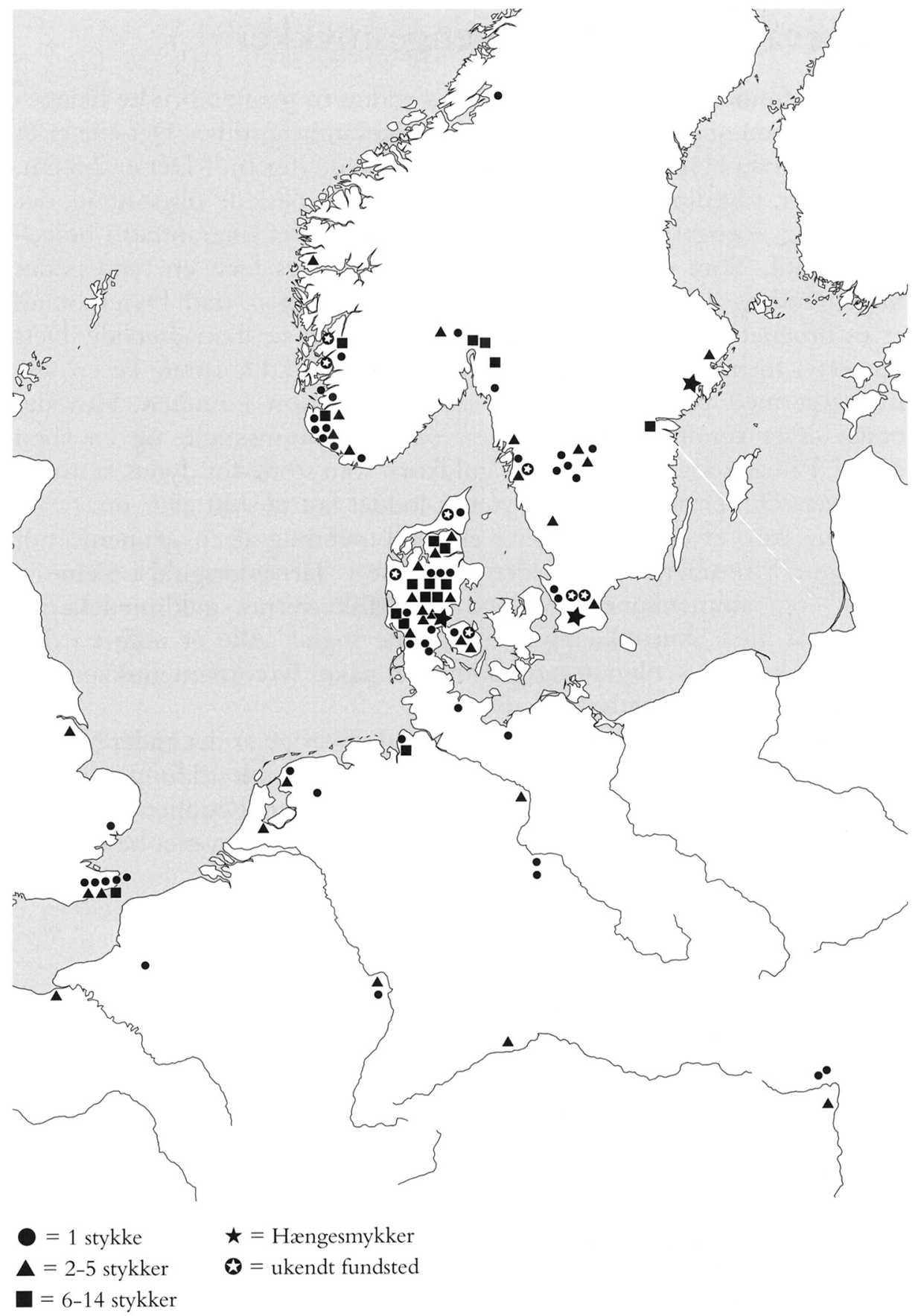

Fig. 5. D-brakteaternes udbredelse i Europa. Hver figur markerer ét fundsted. Tegning: Louise Hilmar.

The distribution of D-bracteates in Europe. Each symbol marks one find spot. Drawing by Louise Hilmar. 


\section{Folkevandringstidens hængesmykker}

Foruden fundet fra Elbæk Skov kendes endnu to gennembrudte hængesmykker med filigran og dyremotiv fra folkevandringstiden. Det ene er et enkeltfund fra Hylteberga i Skurup sogn i Skåne (fig. 6). ${ }^{18}$ Det er $2,5 \mathrm{~cm}$. i diameter. Øsknet er riflet og sat henover den perlede filigrantråd, der løber langs hængesmykkets kant. I borten ses perlet filigrantråd i bølgeornamentik. Som omkransning af dyremotivet ses først en tynd perlet filigrantråd og dernæst en tilsvarende noget kraftigere tråd. Dyremotivet er et firbenet dyr med et for- og bagben. Dyret er fremadseende. Dets krop er s-formet og prydet med perlet filigrantråd. De runde lår er også markeret med perlet filigrantråd samt granulation i midten. Hovedet består af et rundt øje, udformet af en granulationskugle, og en åben mund. På bagsiden ses påloddede guldkorn som støtte for dyrets fæstning til skiven. Det er usikkert, om dyret er loddet fast til sidst eller, om guldkornene bare er en forstærkning eller udsmykning af en gennembrudt dyrefigur. Strømberg omtaler dette smykke i "Järnåldersguld i Skåne" i $1963^{19}$ og sammenligner det med guldhalskravernes guldsmedekunst, men også med Skurupknappen fra samme sogn. ${ }^{20}$ Alle er udført i den samme teknik, dvs. filigran og granulation påsat dyreornamentikken. De viser også alle et fremadseende dyr.

I Skenäs, V.Vingåker sogn, Södermanland i Sverige er det andet brakteatlignende hængesmykke med dyrefigur i gennembrudt stil fundet (fig. 7). Dyret er firbenet, men der ses kun ét for- og bagben. Kroppen er lille og tæt. I forlængelse af kroppen ses et sammenrullet lår. Hovedet består af et

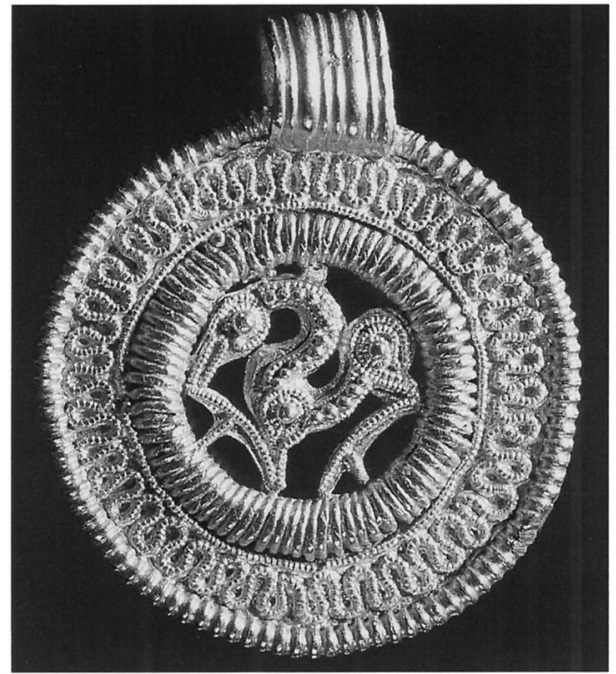

Fig. 6. Guldhængesmykke fra Hylteberga i Skåne. Diameter $2,5 \mathrm{~cm}$. Foto: Bengt Almgren, Lund Universitets Historiska Museet.

The pendant from Hylteberga in Scania, Sweden. Diameter $2.5 \mathrm{~cm}$. Photographed by Bengt Almgren, Lund Universitets Historika Museet. 
Fig. 7. Guldhængesmykke fra Skenäs i Södermanland. Diameter 2,2 cm. Foto: Ulf Bruxe, Historiska Museet i Stockholm.

The pendant from Skenäs in Södermanland, Sweden. Diameter $2.5 \mathrm{~cm}$. Photographed by Ulf Bruxe, Historiska Museet in Stockholm, Sweden.

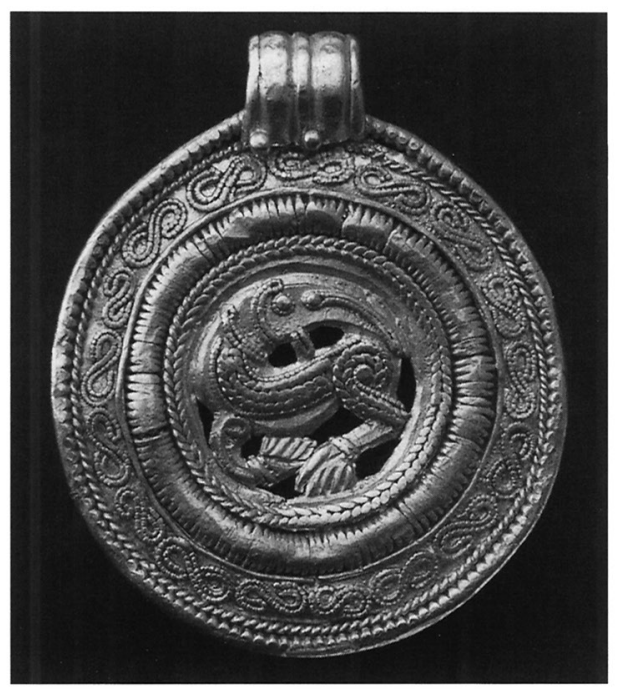

spidst næb og et rundt øje med en halvrund øjebue. Dyret er bagudseende. Under hagen ses antydningen af et skæg. Fødderne er frynsede.

Gennembruddet ses bedst fra bagsiden, idet smykket består af en ret tyk guldplade. Det er formodentlig udført med mejsel fra denne side, men dyrefiguren kan også være loddet på til sidst. Smykket har riflet øsken og perlet filigrantråd på kanten. Derudover ses S-formede filigranfigurer $\mathrm{i}$ borten indrammet af to tynde filigrantråde. Imellem bortens ornamentik og dyret ses to filigrantråde - først en ret kraftig, perlet filigrantråd og dernæst to noget tyndere tilsvarende tråde. Igen dominerer de perlede filigrantråde ornamentikken.

Dette hængesmykke blev betegnet som en F-brakteat af Montelius i midten af forrige århundrede. ${ }^{21}$ Han ændrer det dog til D-gruppen i et senere værk. ${ }^{22}$ Senere bliver smykket taget ud af guldbrakteatgruppen både af Lindqvist ${ }^{23}$, af Öberg ${ }^{24}$ og af Mackeprang ${ }^{25}$. Begrundelsen er den tekniske udførelse, som gør smykket til et filigranprydet hængesmykke i stedet for en brakteat. Men Öberg bruger det dog til en stilistisk sammenligning med dyrene på D-brakteaterne. Han sæetter det i gruppe med en brakteat fra Vättlösa,Västergötland og en fra Stavijordet, Østnorge. Öberg og Lindqvist ser den som en stilistisk parallel til den treringede halskrave fra Ålleberg. ${ }^{26}$

De tre hængesmykker - Elbæk Skov, Hylteberga og Skenäs - med dyreornamentik kan sammenlignes med brakteatgruppen og må ses som en del af den stilistiske udvikling indenfor D-brakteaterne. Deres udbredelse falder i tråd med den udbredelse, som D-brakteaterne har (fig. 4). 


\section{Datering}

De tre nævnte hængesmykker kan dateres indenfor dyreornamentikkens Stil I, der er en selvstændig stil fra sidste fjerdedel af 5. årh. ${ }^{27}$ Diskussionen om stilens ophør og overgang til Stil II pågår stadigvæk. ${ }^{28}$ Jeg vil her fremsætte ældre arkæologers dateringer af smykket fra Hylteberga og Skenäs. Til sidst vil jeg forsøge at datere det nye hængesmykke fra Elbæk Skov og vise i hvilken typologisk sammenhæng, det skal placeres.

Den første, der samlet behandlede filigransmykkerne, var Lindqvist. ${ }^{29}$ Han daterede alle folkevandringstidens smykker med filigran til at være produceret $i$ en kort periode af 5 . årh. Mackeprang tog gruppen op i sit omfattende arbejde med guldbrakteater og daterede denne gruppe noget senere. Han placerede produktionen i første halvdel af 7. årh. ${ }^{30}$ Senere så Munksgaard på filigrangruppen, da hun ville datere det dengang nye fund fra Kitnæs, Sjælland. ${ }^{31}$ Hun argumenterer for en relativ kronologisk udvikling af de forskellige smykker, der er prydet med filigran. Hun går tilbage til Lindqvists tidlige dateringer, men daterer smykkerne over et længere stræk fra midten af 5. årh. og til midten af 6. årh. I 1981 tager Haseloff gruppen op i sit store værk om Salins Stil I. ${ }^{32}$ Han vælger at følge Munksgaards relative datering, men er ikke helt enig i den tilnærmede absolutte datering, som Munksgaard giver.

Halskraven fra Ålleberg i Västergötland, Sverige er et af de tidligste smykker med filigran fra folkevandringstiden. Kraven er treringet og dekoreret med filigran og granulation samt med små guldblikfigurer mellem ringene. Dyreornamentikken dateres til Stil I, men der er stilistiske træk fra den foregående stil, Nydamstilen. Der findes både fremad- og bagudseende dyr på halskraven, og den dateres til midten af 5 . årh. eller muligvis lidt ældre. Dateringen bygger på norske fibler i Nydamstil (f.eks. Nordheim, Vestfold og Hol, Nord Trøndelag). ${ }^{33}$ Halskraverne fra Färjestaden, Öland med fem ringe og fra Möne,Västergotland med syv ringe er karakteristiske for Stil I og må være produceret højst én generation efter Ålleberg. ${ }^{34}$ I samme stil og derved med omtrent samme datering skal ringen fra Hannenov, Falster og sværdknappen fra Skurup grupperes. ${ }^{35}$ Strömberg ser ornamentikken på Hylteberga $i$ tråd med den på sværdknappen fra Skurup. På den ene side af sværdknappen ses et fremadseende dyr, der viser stilistisk lighed med dyret fra Hylteberga. Det sammenrullede lår på et fremadseende dyr med åben øjenbue går igen på de to stykker. Filigranteknikken på hængesmykket og sværdknappen minder meget om hinanden, og det kan ikke udelukkes, at det er den samme guldsmed, der har fremstillet begge genstande. ${ }^{36}$ Dyreornamentikken på sværdknappen og på hængesmykket er en videreudvikling af dyrene på halskraverne, og disse må derfor dateres lidt yngre - til begyndelsen af 6 . 
Fig. 8. Pragtfibel fundet ved Skodborghus i Sønderjylland samt tegning af ornamentikken på fiblens fod. Længde 9,7 cm. Foto: Nationalmuseet. Tegning: Efter Haseloff 1981 s. 240 Abb. 144. 2:1.

The fibula found at Skodborghus in Southern Jutland and drawing of the ornament on the foot of the fibula. Photographed by The $\mathrm{Na}-$ tional Museum. Drawing: After Haseloff 1981 p. 240 Abb. 144. Scale 2:1.
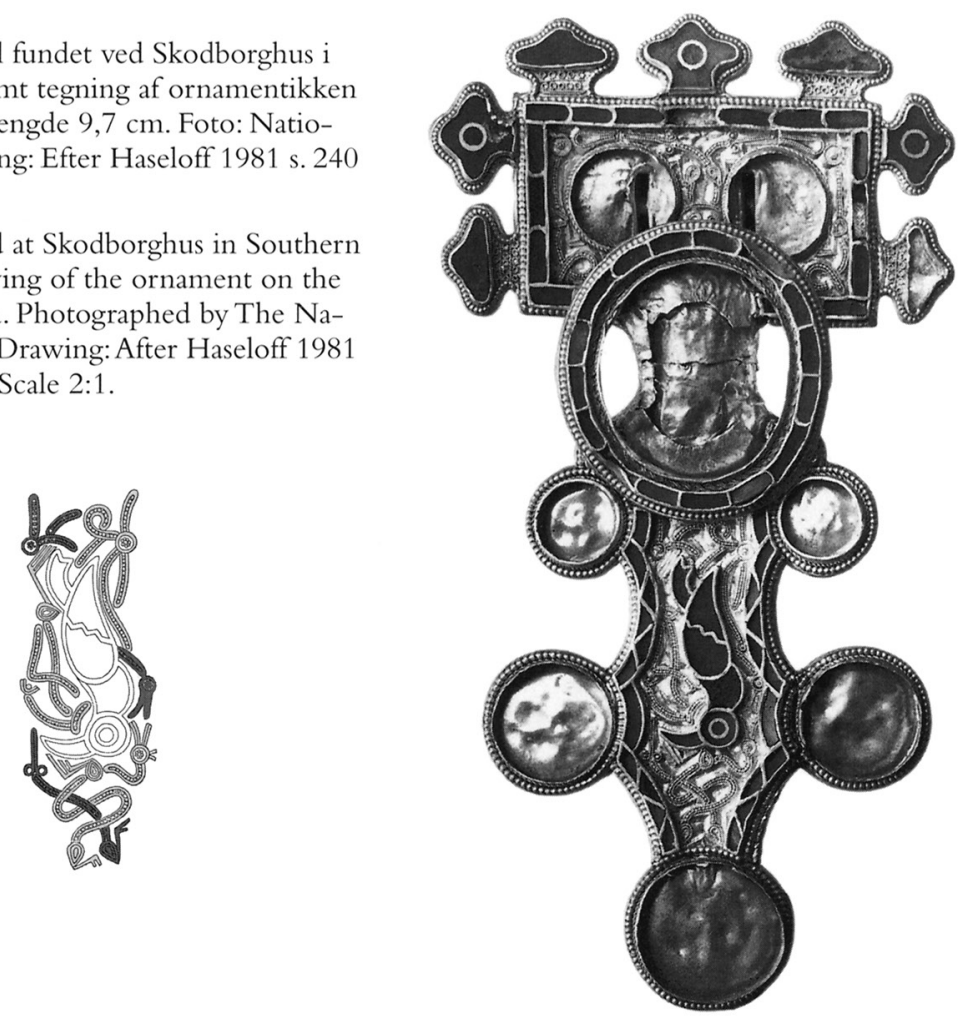

årh. ${ }^{37}$ Også smykket fra Skenäs er sammenlignet med halskraven fra Ålleberg. Lindqvist kommenterer, at Skenässmykkets dyr ikke er så realistisk som de bedste af dyrene på den treleddede halskrave fra Ålleberg. ${ }^{38}$ Han daterer Skenässmykket til første halvdel af 400-tallet pga. ligheden med halskraven. Öberg opfatter hængesmykket som en af de ældste typer af D-brakteater med bagudseende dyr. ${ }^{39}$ Siden er smykket blevet glemt og er ikke med i hverken Mackeprang, Munksgaard eller Haseloffs stilistiske dateringer. Sammenligningen med halskraven fra Ålleberg og de lidt yngre halskraver fra Färjestaden og Möne giver en datering af Skenäs-smykket til begyndelsen af 6 . årh ligesom hængesmykket fra Hylteberga.

En lidt usædvanlig gruppe med filigran er de flotte filigranfibler, hvoraf der er fundet fem stykker, alle fra Danmark. Fiblerne fra Adslev og Nørre Tranders i Jylland er fragmenterede. På Elsehovedfiblen fra Sydvestfyn er kun bevaret hovedpladen. Den ovennævnte Kitnæs fibel fra Sjælland og en fibel fra Skodborghus i Sønderjylland er begge hele. Kitnæsfiblen er den ældste, og den dateres til omkring 475 e.Kr. af Haseloff, mens Munksgaard daterer den til omkring 500 e. Kr. ${ }^{40}$ Forskellen skyldes, at Haseloff sætter overgangen mellem Nydamstilen og Stil I til omkring 
475 e.Kr., mens Munksgaard sætter den til omkring 500 e.Kr. De er enige om, at Kitnæs fiblen ligger på overgangen mellem de to stile, men er altså ikke enige om, hvornår overgangen skal sættes. Overgangen mellem de to stile kan være skiftende i forskellige regioner, og et vist overlap må forventes ${ }^{41}$ Fiblen fra Elsehoved dateres til begyndelsen af 6. årh. af Haseloff på grund af de 10-12 solidi, der er fundet sammen med fiblen. ${ }^{42}$ De syv af dem har prægningstid mellem 425 og 491/518 e.Kr. Skodborghusfiblen dateres til begyndelsen af 6 . årh., idet fuglen med de indlagte halvædelstene på fiblens fod stilistisk kan sammenlignes med sværdgarnituren fra Rommersheim, Rheinhessen. ${ }^{43}$ Denne grav er dateret til tidlig 6. årh.

Dyrene på foden af Skodborghusfiblen kan stilistisk ses i sammenhæng med dyret på hængesmykket fra Elbæk Skov.Vi har her at gøre med et aflangt dyr med et åbent næb (fig. 8). Dyrets krop er langstrakt, og kun lårene er markeret. Hovedet består af et øje med en rund eller åben øjenbue. Da filigranteknik og stilelementer er sammenfaldende, er en sammenligning mulig. Det er især dyret under fuglens næb, som viser stilistisk lighed med dyret på Elbæk Skov smykket. Begge fund kommer desuden fra D-brakteaternes hovedudbredelsesområde, Jylland. Den samme datering som for Skodborghusfiblen er derfor sandsynlig. Elbæk Skov hængesmykket kan således dateres til begyndelsen af 6. årh.

Da de fleste filigranprydede genstande dateres til sidste halvdel af 5 . årh. og begyndelsen af 6. årh., må D-brakteaterne, som i dyrestil og smykkeform er lig de filigranprydede hængesmykker, også dateres til samme periode.

\section{Afslutning}

I forbindelse med et påbegyndt stipendium på Institut for Forhistorisk Arkæologi, Moesgård, er det min hensigt at registere genstande dekoreret i den tidlige dyrestil (Stil I) og fremsætte en nytolkning af den stilistiske udvikling og datering. I den forbindelse er fundet fra Elbæk Skov af stor vigtighed, da det giver mulighed for en krydsdatering mellem filigransmykkerne og brakteaterne.

Dette unikke hængesmykke er bindeleddet mellem brakteaterne og de filigranprydede smykker. Det er uden tvivl skabt som en del af brakteatproduktionen, og det har derfor også været inden for den sammme symbolssfære, men selve udformningen er meget forskellig fra resten af brakteatmaterialet. Fundstedet nær Horsens Fjord er også usædvanligt for denne type smykker. Der er ikke fundet noget brakteatdepot i umiddelbar nærhed af Elbæk Skov. Men det kan ikke udelukkes, at der kan findes flere guldgenstande i nærheden af dette fund. På grund af forskellen 
mellem fundtidspunktet og afleveringstidspunktet, er det ikke muligt at angive fundstedet helt præcis. Skrænten ved Husodde er meget eroderet, og deponeringsstedet kan have ligget i skrænten. Hængesmykket kan være vasket ud af skrænten og derved endt $\mathrm{i}$ vandkanten.

\section{NOTER}

1) En tak til Hans Jørgen Madsen, Moesgård Museum, for opfordring til at publicere guldhængesmykket fra Elbæk Skov.

2) Andersson 1995 s. 128f.

3) Andersson 1995 s. 130.

4) Axboe 1981 s. 39 fig. 42

5) Andersson 1995 s. $128 \mathrm{f}$.

6) Haseloff 1981 s. 231

7) Mackeprang 1952 s. 9 note 1.

8) Mackeprang 1952 og Hauck m.fl. 1985ff.

9) Thomsen 1855 s. $265 f$.

10) Thomsen 1855 s. 279.

11) Montelius 1869.

12) Mackeprang 1952 s. 62.

13) "En stilistisk og kronologisk analyse af D-brakteaterne". Upubliceret hovedfagsspeciale 1996.

14) Andrén 1991 s. 248 fig. 3.

15) Malmer 1977 s. $107 \mathrm{f}$.

16) Malmer 1977 s. 110.

17) Chadwick Hawkes 1981 s. 326.

18) En tak til PeterVang Petersen for at lede min opmærksomhed hen på dette skånske hængesmykke.

19) Strömberg 1963 s. $65 f$.

20) Strömberg 1963 s. 86.

21) Montelius 1869 s. 42 nr. 299.

22) Montelius 1896-1900.

23) Lindqvist 1926 s. 58.

24) Öberg 1942 s. $163 f f$ Grupp VII.

25) Mackeprang 1952 s. 58 note 5.

26) Öberg 1942 s. 164 fig. 157.

27) Haseloff 1981 s. 173 .

28) Bl.a. Høilund Nielsen 1986, Lund Hansen 1992 og Jørgensen og Nørgaard Jørgensen 1997.

29) Lindqvist 1926 s. $55 \mathrm{ff}$.

30) Mackeprang 1952 s. $85 \mathrm{ff}$.

31) Munksgaard 1953 s. $67 \mathrm{ff}$ og 1966 s. $53 \mathrm{ff}$.

32) Haseloff 1981.

33) Haseloff 1981 s. $231 \mathrm{f}$.

34) Arbman 1945 s. $165 f$.

35) Haseloff 1981 s. 231f.

36) Strömberg 1963 s. 86.

37) Haseloff 1981 s. 235.

38) Lindqvist 1921 s. 58.

39) Öberg 1942 s. 187.

40) Munksgaard 1966 s. 60 og Haseloff 1981 s. 237.

41) Näsman 1984 s. 70 Abb. 1.

42) Haseloff 1981 s. 238.

43) Böhner 1954 s. 196. 


\section{LITTERATUR}

Andersson, K. 1995: Romartida guldsmide i Norden III. Övriga smycken, teknisk analys och verkstadsgrupper. Aun 21. Uppsala.

Andrén, A. 1991: Guld och makt - en tolkning av de skandinaviska guldbrakteaternes funktion. Fabech, C. \& J.Ringtved (red.): Samfundsorganisation og regional variation. Norden i romersk jernalder og folkevandringstid.

Arbman, H. 1945: Järnålderen. Tiotusen år i Sverige. Stockholm.

Axboe, M. 1981: The Scandinavian Gold Bracteates. Studies on their manufacture and regional variations. With a supplement to the catalogue of Mogens B. Mackeprang. Acta Archaeologica 52.

Axboe, M. (red.) 1985f: Die Goldbrakteaten der Völkerwanderungszeit. Ikonographischer Katalog 1-3. München.

Böhner, K.: Besprechung von: Mogens B. Mackeprang, De nordiske guldbrakteater (1952). Bonner Jahrbuch 154.

Chadwich Hawkes, S. \& M. Pollard 1981: The Gold Bracteates from sixth Century Anglo-Sason Graves in Kent, in the light of a new find from Fingelsham. Frühmittelalterliche Studien 15.

Haseloff, G. 1981: Die germanischen Tierornamentik der Völkerwanderungszeit. Studien zu Salins's Stil I. Berlin/New York.

Høilund Nielsen, K. 1986: Zur Chronologie der jüngeren germanischen Eisenzeit auf Bornholm. Untersuchungen zu Schmuckgarnituren. Acta Archaeologica 57.

Jørgensen,L. \& A. Nørgård Jørgensen 1997: Norre Sandegård Vest. A cemetery from $6^{\text {th }}$ - $8^{\text {th }}$ Centuries on Bornholm. København.

Lindqvist, S. 1926: Vendelkulturens ålder och ursprung. Stockholm.

Lund Hansen, U. 1992: Die Hortproblematik im Licht der neuen Diskussion zur Chronologie und zur Deutung der Goldschätze in derVölkerwanderungszeit. Hauck, K.(red.): Der historische Horizont der Götterbild-Amulette aus der Übergangsepoche von der Spätantike zum Frühmittelalter. Bericht über das Colloquium vom 28.11-1.12 1988 in der Werner-Reimers Stiftung, Bad Homburg. Göttingen.

Mackeprang, M. 1952: De nordiske Guldbrakteater. Århus.

Malmer, M. 1977: Chronologie der Solidi und Brakteaten. Kossac,G. \& Reichstein J. (red.): Archäologische Beitrage zur Chronologie der Völkerwanderungszeit. Bonn.

Montelius, O. 1869: Från Jernålderen. Stockholm.

Montelius, O. 1896-1900: Den nordiska jernålderns kronologi. I-III. Stockholm.

Munksgaard, E. 1953: Collared gold necklets and armlets. A Remarkable Danish Fifth Century Group. Acta Archaeologica 24.

Näsman U. 1984: Zwei Relieffibeln von der Insel Öland. Praehistorische Zeitschrift 59/1.

Strömberg, M. 1963: Järnåldersguld i Skåne. Lund.

Thomsen, C.J. 1855: Om Guldbracteaterne og Bracteaternes tidligste Brug som Mynt. Annaler for nordisk Oldkyndighed.

Öberg, H. 1942: Guldbrakteaterna frain Nordens folkevandringstid. Uppsala. 


\section{A pendant related to the gold bracteates}

In the late 193()s, a unique gold pendant from the period of the great migrations was found at Elbrk Skov, Husodde, on the northern side of Horsens Fjord (fig. 1). Almost 60) years later, in the beginning of 1998 , it was handed over to Forhistorisk Museum, Moesgård. (Fig. 2)

The pendant is a thin golden plate with a loop. It weighs 2.8 grams and has a diameter of $2.2 \mathrm{~cm}$. The plate has open-work ornament of a four-legged fabulous beast (fig. 3). A filigree pearl-pattern runs along the outer and inner edge of the border, and the border itself has a pretzel-shaped ornament made in a similar way. The animal motif is decorated with filigree, which gives it a relief effect similar to that on the various bracteate types.

The open-work pattern was probably made using a chisel from the back of the plate. The pendant has been repaired with a thin gold plate on the back, as the attachment for the border turned out to be too thin (fig.2). The loop has no visible wear but the filigree on the motif; the border and the edge are worn.

The style of the pendant from Elbæk Skov is similar to the animal style on the I)bracteates (fig. 4). The distribution map (fig. $5)$ shows finds of D-bracteates. It is worth noticing that no I)-bracteates have been found on Zealand and the surrounding islands, or on Bornholm. A stylistic and chro- nological analysis has shown that the early types appear in Jutland. Later they are exported, copied and imitated outside Southern Scandinavia.

In Sweden one open-work pendant with a filigree animal figure has been found at Hylteberga in Scania (fig. 6) and another one at Skenäs in Södermanland (fig. 7). Comparing these with the Swedish neck collars from the 6th century, the Swedish pendants can be stylistically dated to the same time. The dating of the Elbrk Skov piece is based partly on the dating of the D-bracteates and partly on the animal ornamentation on the fibula from Skodborghus (fig. 8). On this basis the Elbæk Skov pendant is preliminarily dated to the early 6th century.

This dating relies on past archaeological interpretations. The author of this article holds a scholarship which will develop a new interpretation of the development and dating of the early animal style (Style I). The Elbre Skov pendant is important to this chronology, as it connects the filigree pieces with the bracteates.

Elisabeth Barfod Carlsen Institut for Forhistorisk Arkæologi, Aarhus Universitet Moesgård

Translated by Annette Lerche Trolle 
